\title{
A STUDY ON FATIGUE STRENGTH OF STEEL- CONCRETE SANDWICH BEAMS WITHOUT SHEAR REINFORCEMENT
}

\author{
Mohab ZAHRAN ${ }^{1}$, Tamon UEDA $^{2}$ and Yoshio KAKUTA ${ }^{2}$ \\ ${ }^{1}$ Member of JSCE, Dr., Former graduate student, Dept. of Civil Eng., Hokkaido University (Kita 13, \\ Nishi 8, Kita-ku, Sapporo, 060, Japan) \\ ${ }^{2}$ Member of JSCE, Dr., Dept. of Civil Eng., Hokkaido University (Kita 13, Nishi 8, Kita-ku, Sapporo, \\ 060, Japan)
}

\begin{abstract}
Fatigue tests were carried out for steel-concrete sandwich beams without shear reinforcement. Observed failure modes and their experimental $S-N$ relationships for this type of beams are presented. The fatigue strength of the sandwich beams was predicted analytically by using the finite element method. The fatigue analysis was based upon reducing the compressive strength, the tensile strength, and the stiffness of the concrete with increasing the number of loading cycles $(N)$ and increasing the stress range $\left(S_{r}\right)$. The analytical $\boldsymbol{S}-\boldsymbol{N}$ relationships are compared with the experimental ones. Finally, a design proposal for the sandwich beams under fatigue loading is presented.
\end{abstract}

Key Words: fatigue strength, finite element analysis, shear, steel-concrete sandwich beam

\section{INTRODUCTION}

The steel-concrete sandwich member is composed of core concrete, steel skin plates, and shear connectors (i.e., steel angles) as shown in Fig.1. The sandwich members have practical applications in various structures such as tunnels, bridge decks, marine structures, etc. Marine structures are subjected to wave forces repeatedly. Bridge decks are also subjected to traffic loads repeatedly. These repetitive loads may result in progressive cracking and sometimes crushing of the core concrete if the load amplitude is sufficiently large. The sandwich member has many weldings between the steel plates and the steel angles. These weldings may result in fatigue fracture of the steel plates. Therefore, the fatigue endurance of the steelconcrete sandwich members has to be adequately investigated. The flexural capacity and the shear capacity of this type of members have been thoroughly investigated under static loading conditions. Hence, the design code for steelconcrete sandwich structures has been proposed recently ${ }^{1)}$. However, there have been few researches regarding the fatigue strength of steel-concrete sandwich members ${ }^{2), 3)}$. This study presents experimentally and analytically the fatigue strength of steel-concrete sandwich beams without shear reinforcement. Only one-sided cyclic loading is investigated in this study.

\section{EXPERIMENTAL WORK ${ }^{4)}$}

The steel-concrete sandwich beam investigated in this study is shown in Fig.1. The cross section of the sandwich beam was $250 \times 400 \mathrm{~mm}$ and the span length was $2.65 \mathrm{~m}$. The sandwich beam was tested by two symmetrical concentrated loads, and the shear span to effective depth ratio $(\boldsymbol{a} / \boldsymbol{d})$ was equal to 3.0. The thickness of the steel skin plates was $16 \mathrm{~mm}$. The yield strength of the steel plates $\left(f_{y}\right)$ was equal to $400 \mathrm{MPa}$. The compressive strength of the concrete $\left(f_{c}{ }^{\prime}\right)$ was $25 \mathrm{MPa}$. Steel angles of $40 \times 40 \times 4 \mathrm{~mm}$ size were used as shear connectors which were welded to the steel skin plates. Tests were carried out for eight specimens. Specimen no.1 was tested under static monotonic loading while the other seven specimens were tested under fatigue loading. In the fatigue tests, the specimens were loaded in a sinusoidal waveform and the loading frequency was $4.0 \mathrm{~Hz}$. The minimum fatigue load $\left(\boldsymbol{P}_{\min }\right)$ was kept constant at 20 $\mathrm{kN}$ which is about $6 \%$ of the static load carrying capacity of the beam $\left(\boldsymbol{P}_{u, \text { exp }}\right)$. For specimens no.2, 3, 4, 5, 6, 7, and 8, the maximum fatigue load $\left(\boldsymbol{P}_{\max }\right)$ was equal to $38.7 \%, 49.0 \%, 63.2 \%, 70.7 \%, 82.1 \%$, $43.1 \%$, and $58.5 \%$, respectively of $\boldsymbol{P}_{\boldsymbol{u} \text { exp. }}$. For 


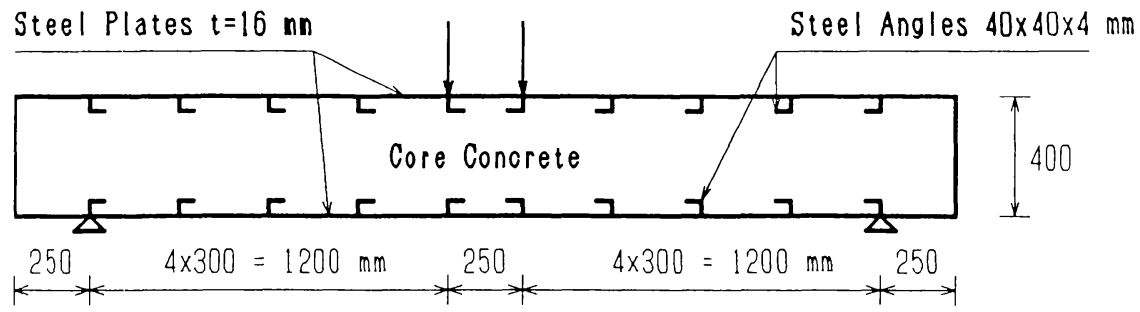

Fig.1 Geometry and loading configuration of the sandwich beam

specimen no.2, the fatigue failure did not occur until $2 \times 10^{6}$ cycles and therefore the maximum load was increased to $65.5 \%$ of $\boldsymbol{P}_{u, \exp }$.

\section{FINITE ELEMENT ANALYSIS ${ }^{5)}$}

\section{(1) Finite element idealization}

A nonlinear finite element method computer program (WCOMR) ${ }^{6}$ was used to analyze the steelconcrete sandwich beam shown in Fig.1. The finite element mesh of the beam is shown in Fig.2. For the concrete and steel elements, eight-node quadratic elements were used. Each concrete and steel element contains $(3 \times 3)$ Gauss points. The constitutive models for the concrete and steel elements are given in references 6) and 7). Bond elements were provided to simulate the shear connectors and the interface between the concrete and the lower steel plate. A linear bond stress-slip relationship was adopted as a constitutive law for the bond elements ${ }^{7}$. Prescribed displacements were given at the loading point as shown in Fig.2.

\section{(2) Analytical models for fatigue}

An experimental $S-N$ relationship was adopted as a constitutive law for concrete under fatigue loading. This $S-N$ relationship is given by the following equation,

$$
\left(f_{\max } / f_{u}\right)=1.0-0.0685(1-R) \log N
$$

where: $f_{u}=$ the static strength

$$
\begin{aligned}
& R=f_{\min } / f_{\max } \quad(0 \leqq \mathrm{R} \leqq 1.0) \\
& f_{\min }=\text { the minimum stress } \\
& f_{\max }=\text { the maximum stress } \\
& \boldsymbol{N}=\text { the number of loading cycles }
\end{aligned}
$$

This $\boldsymbol{S}-\boldsymbol{N}$ relationship was proposed by Tepfers ${ }^{8) .9)}$ to predict the tensile and compressive fatigue strengths of plain concrete. For an input number of loading cycles $(N)$, Eq.(1) was used to check the tensile and compressive fatigue failure at every
Prescribed displacement

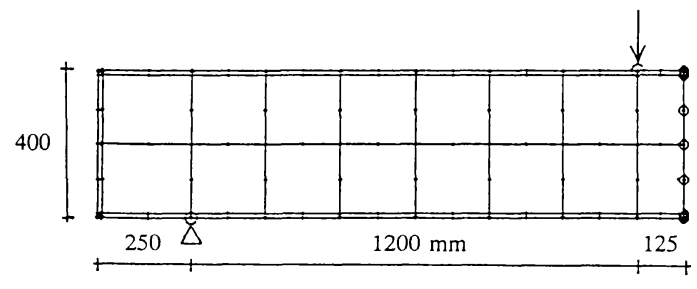

Fig.2 The finite element mesh

concrete Gauss point according to the biaxial stress state at this point. If compressive fatigue failure occurs at one Gauss point, the compressive strength of this point is reduced to a stress at which the fatigue failure occurs. Similarly, if tensile fatigue failure occurs at one Gauss point, the tensile strength of this point is reduced.

A number of previous studies ${ }^{10), 11)}$ have indicated that the secant modulus of elasticity of concrete $\left(\boldsymbol{E}_{\boldsymbol{s}}\right)$ is reduced during the fatigue loading. Therefore, the linear relationship shown in Fig.3 was adopted in this study to model the stiffness degradation of concrete under fatigue loading. This linear relationship is given by the following equation,

$$
R_{N}=299-2.99\left(E_{f} / E_{s}\right)
$$

where: $\left(\boldsymbol{E}_{f} / \boldsymbol{E}_{\varsigma}\right)$ in percentage

$E_{s}=$ the modulus of elasticity of concrete under static loading

$\boldsymbol{E}_{f}=$ the reduced modulus of elasticity of concrete under the fatigue loading

$\boldsymbol{R}_{N}=$ the percentage consumed of the fatigue life

Therefore, the fatigue analysis was based upon reducing the strength and the stiffness of the concrete at Gauss points with increasing the input 


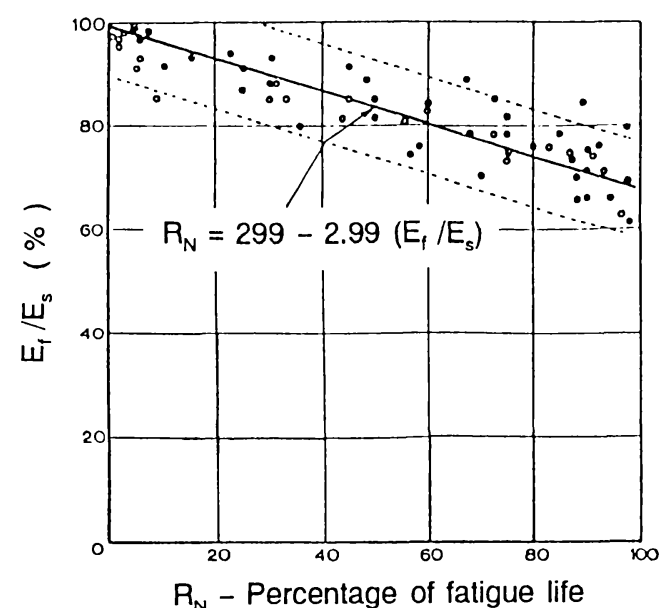

Fig.3 Decrease of modulus of elasticity under repeated loading ${ }^{11}$

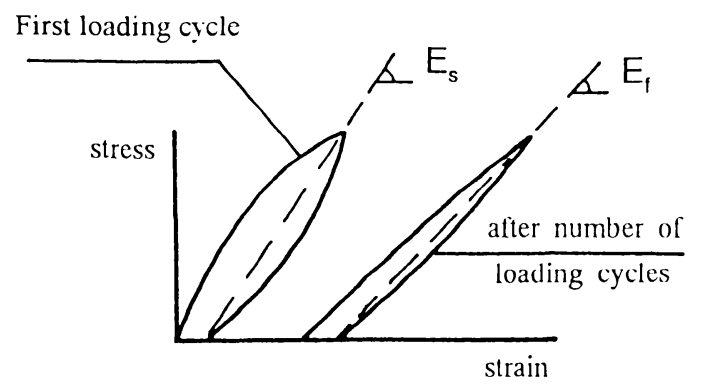

number of loading cycles $(N)$ or increasing the stress range $\left(S_{r}=f_{\max }-f_{\min }\right)$.

\section{(3) Analysis procedure}

The analysis procedure used in this study is illustrated in Fig.4. At first, a static loading cycle $(\mathrm{OAB})$ is applied. The maximum principal compressive and tensile stresses at every concrete Gauss point $\left(\sigma_{c \max } \sigma_{t_{\max }}\right)$ are stored at point A. Similarly, the minimum principal compressive and tensile stresses at every concrete Gauss point $\left(\sigma_{c \min }, \sigma_{t \min }\right)$ are stored at point B. Then, these stored principal stresses are used to calculate the mean and the deviatoric stresses as shown in Fig. $\mathbf{5}^{6)}$, hence:

$$
\begin{aligned}
& \sigma_{\text {m,max }}=\sqrt{2} / 2\left(\sigma_{t \max }+\sigma_{c \max }\right) \\
& \tau_{d, \max }=\sqrt{2} / 2\left(\sigma_{t \max }-\sigma_{c \max }\right)
\end{aligned}
$$

similarly:

$$
\begin{aligned}
& \sigma_{m, \min }=\sqrt{2} / 2\left(\sigma_{t \min }+\sigma_{c \min }\right) \\
& \tau_{d, \min }=\sqrt{2} / 2\left(\sigma_{t \min }-\sigma_{c \min }\right)
\end{aligned}
$$

Thereafter, the maximum and minimum equivalent stresses $\left(S_{\max }, \dot{S}_{\min }\right)$ are calculated as shown in Fig. ${ }^{6}$, hence:

$$
\begin{aligned}
& S_{\text {max }}=\left[\left(a \sigma_{m, \max }\right)^{2}+\left(b \tau_{d, \max }\right)^{2}\right]^{0.5} \leqq 1.0 \\
& S_{\text {min }}=\left[\left(a \sigma_{m, \min }\right)^{2}+\left(b \tau_{d, \text { min }}\right)^{2}\right]^{0.5} \leqq 1.0
\end{aligned}
$$

$$
\text { where : } a=0.6 / f_{c}{ }^{\prime} \quad, \quad b=1.3 / f_{c}{ }^{\prime}
$$

These equivalent stresses $\left(S_{\max }, S_{\min }\right)$ indicate the level of applied stresses at any Gauss point under the plane stress condition. Then, substituting $\left(f_{\max }=\right.$ $\left.S_{\text {max }}\right),\left(f_{\min }=S_{\text {min }}\right)$, and $\left(f_{u}=1.0\right)$ in Eq.(1), the number of loading cycles $\left(\boldsymbol{N}_{C}\right)$ could be calculated. The number of cycles $\left(\boldsymbol{N}_{C}\right)$ is defined as the number of loading cycles required to induce compression fatigue failure at this concrete Gauss point.

The stored principal stresses are also used together with the cracking criterion of concrete as shown in Figs.7(a) and 7(b). In Fig.7(a), the point $\left(\sigma_{t \min }, \sigma_{c \min }\right)$ is plotted, and hence the ratio $\left(\boldsymbol{R}_{\min }\right)$ is calculated as,

$$
R_{\min }=\sigma_{t \min } / f_{t l} \leqq 1.0
$$

Similarly, in Fig.7(b), the point $\left(\sigma_{t_{\max }}, \sigma_{c \max }\right)$ is plotted, and hence the ratio $\left(\boldsymbol{R}_{\max }\right)$ is calculated as,

$$
R_{\max }=\sigma_{t \max } / f_{t 2} \leqq 1.0
$$

Where $f_{t l}$ and $f_{t 2}$ are the tensile stresses at cracking of the concrete Gauss point. Then, substituting $\left(f_{\max }=R_{\max }\right),\left(f_{\min }=R_{\min }\right)$, and $\left(f_{u}=1.0\right)$ in Eq. (1), the number of loading cycles $\left(N_{T}\right)$ could be calculated. The number of cycles $\left(\boldsymbol{N}_{T}\right)$ is defined as the number of loading cycles required to induce tensile fatigue failure at this concrete Gauss point.

Thereafter, a second loading cycle (BCD) is applied with an input number of fatigue loading cycles $\left(N_{l}\right)$ (see Fig.4). The input number of cycles $\left(N_{I}\right)$ is compared with the calculated ones $\left(N_{C}\right.$ and $N_{T}$ ):

- if $N_{I} \geqq N_{C}$, the concrete Gauss point is considered to fail in compression, and therefore, the compressive strength of this Gauss point is reduced to $\left[f_{c}{ }^{\prime} \times S_{\max }\right]$. 


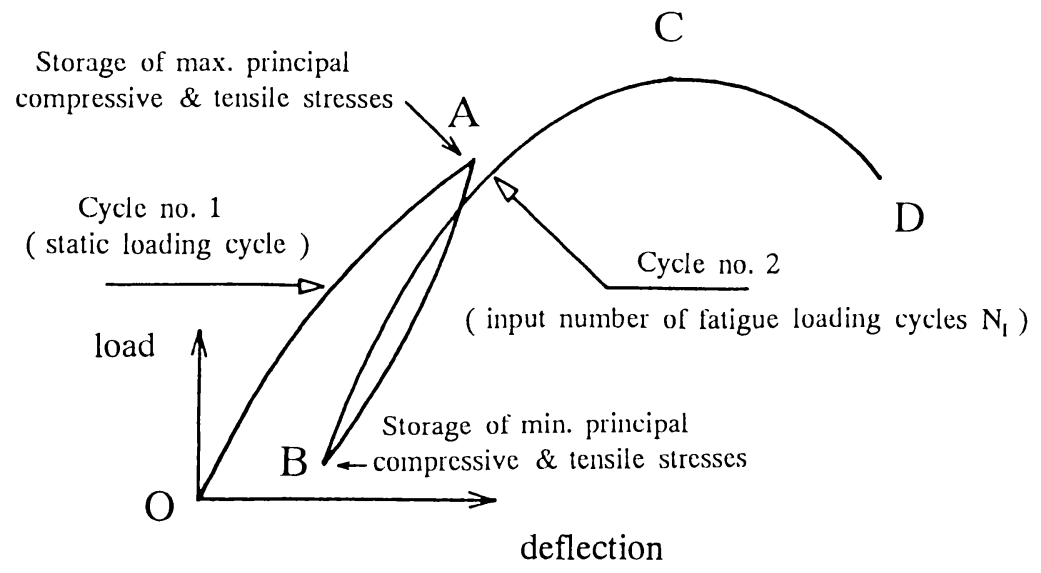

Fig.4 Analysis procedure

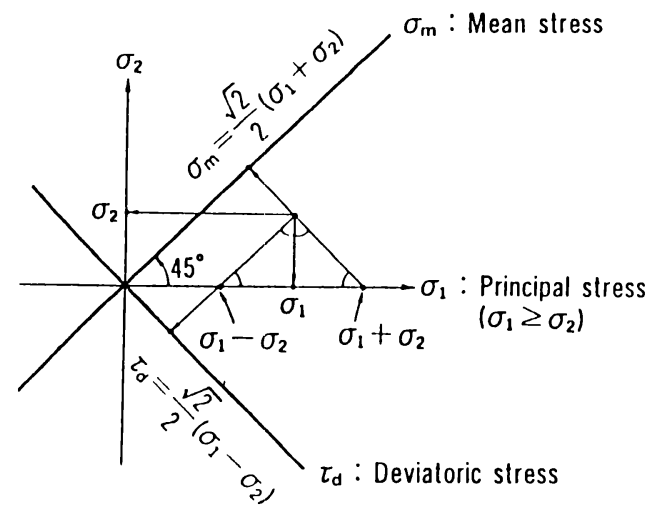

Fig.5 Mean and deviatoric stress coordinates ${ }^{6)}$

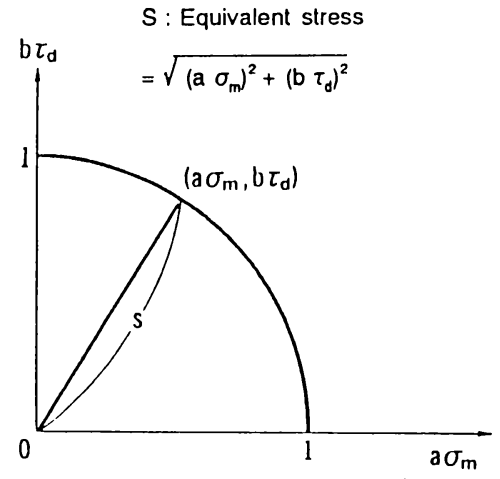

Fig.6 Definition of equivalent stress ${ }^{6)}$

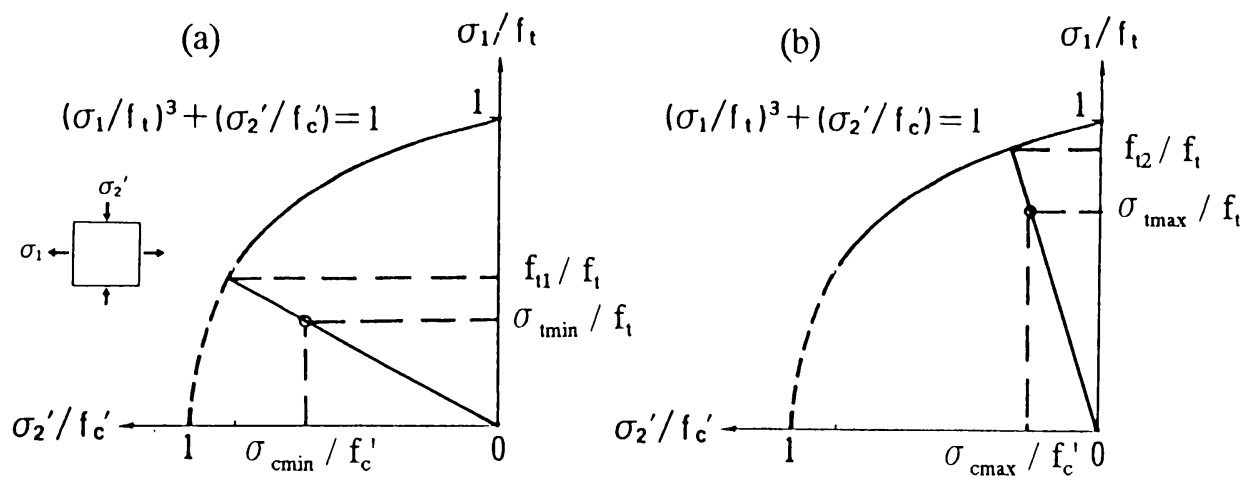

Fig.7 Cracking criterion for concrete (biaxial tension-compression) ${ }^{6)}$ 


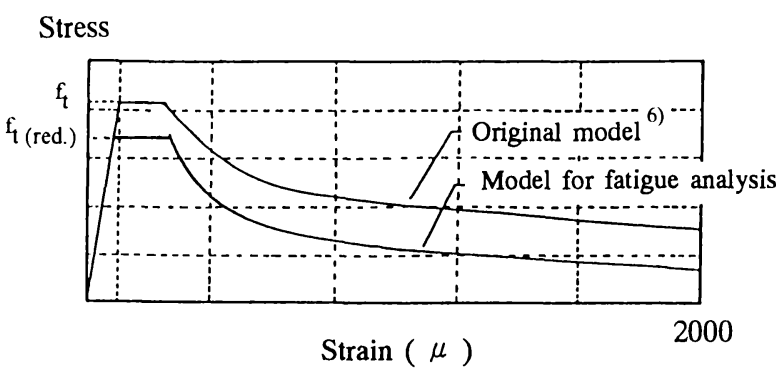

Fig.8 Tension stiffening model for the fatigue analysis

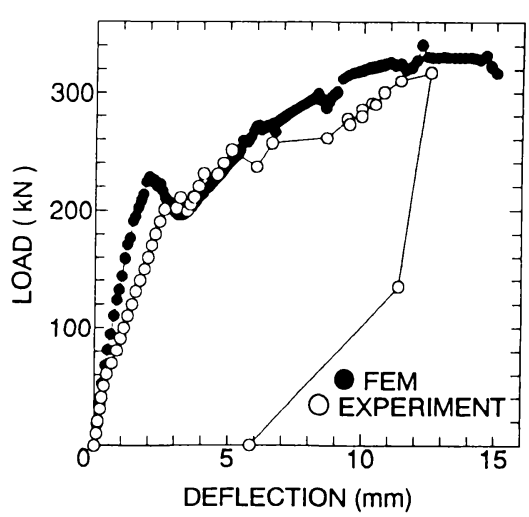

Fig.9 Load-deflection curves under static loading
- if $N_{I} \geqq N_{T}$, the concrete Gauss point is considered to fail in tension, and therefore, the tensile strength of this Gauss point is reduced to [ $f_{t}$ $\times \boldsymbol{R}_{\max }$ ]. Also, the stiffness of concrete is reduced to $66 \%$ of the initial stiffness. The ratio $66 \%$ is the minimum value given by Eq. (2) when $\left(\boldsymbol{R}_{N}=100 \%\right)$.

- if $N_{I}<N_{T}$, the concrete Gauss point is considered not to have failed in tension yet. In this case, the stiffness of concrete is reduced according to Eq.(2), in which the percentage of fatigue life $\left(\boldsymbol{R}_{N}\right)$ is given by,

$$
R_{N}=\left(N_{I} / N_{T}\right) \times 100
$$

The reduction in the tensile strength of the concrete $\left(f_{t}\right)$ will result in earlier cracking for the concrete Gauss points. If the Gauss point is already cracked, the reduction in $f_{t}$ will result in downward shift for the tension stiffening branch of concrete as shown in Fig.8. Hence, for the same tensile strain (i.e., crack opening), the tensile force transferred normal to the crack surface will be reduced. The model for fatigue analysis in Fig.8 is given by the following equation,

$$
\sigma_{t} / f_{t}=\beta\left(\varepsilon_{t u} / \varepsilon_{\imath}\right)^{0.4}
$$

where: $\sigma_{t}=$ the tensile stress

$\varepsilon_{t}=$ the tensile strain

$f_{t}=$ the tensile strength of concrete

$\varepsilon_{t u}=0.02 \%$

$\beta=$ reduction factor for fatigue analysis

On the other hand, the reduction in the stiffness of the uncracked concrete Gauss points $\left(\boldsymbol{E}_{c}\right)$ will weaken the stiffness of the concrete elements. Also, the reduction in the stiffness of concrete $\left(E_{c}\right)$ results in decreasing the shear modulus of concrete $\left(\boldsymbol{G}_{\boldsymbol{c}}\right)$ which in turn results in decreasing the shear force transferred parallel to the crack surface. The reduction of the tensile and shear forces transferred at the crack surface could be a convenient model to simulate the increase in crack width under fatigue loading. Since the effect of the reduction in the concrete stiffness due to the fatigue of concrete in compression was found to be negligible, only the reduction in the concrete stiffness due to the fatigue of concrete in tension was considered as described in the cases of $N_{I} \geqq N_{T}$ and $N_{I}<N_{T}$.

Therefore, during the second loading cycle (BCD) in Fig.4, the strength and the stiffness of the concrete Gauss points are reduced, which in turn results in reducing the overall stiffness of the sandwich beam. Finally, the sandwich beam is considered to fail due to the fatigue loading $\left(\boldsymbol{N}_{\boldsymbol{I}}\right.$ cycles) if the peak load of the second cycle (point $\mathrm{C}$ in Fig.4) is approximately equal to the peak load of the first cycle (point $\mathrm{A}$ in Fig.4). In this case, the input number of cycles $\left(N_{I}\right)$ is considered to be equal to the fatigue life of the sandwich beam. Note that in this study, it is simply assumed that Eq.(1) is applicable to the biaxial state of stresses $\left(\left(S_{\max }, S_{\min }\right)\right.$ and $\left.\left(\boldsymbol{R}_{\max } \boldsymbol{R}_{\min }\right)\right)$. Further study is necessary to prove this assumption by fatigue tests of concrete elements under biaxial stress conditions.

\section{RESULTS AND DISCUSSION}

\section{(1) Static monotonic loading}

At first, the sandwich beam (specimen no.1) was tested under static monotonic loading. The sandwich beam was also analyzed under static monotonic loading by using the finite element method. The experimental as well as the analytical load-deflection curves are shown in Fig.9. It is observed that the load increases with high stiffness 


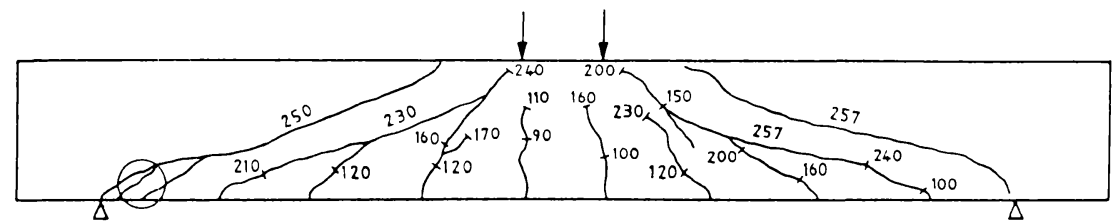

Crushing of concrete

(numbers indicate the load value in $\mathrm{kN}$ )

Fig.10 Crack pattern under static monotonic loading

Table 1 Results of the fatigue tests

\begin{tabular}{|c|c|c|c|c||}
\hline $\begin{array}{c}\text { Spesimen } \\
\text { No. }\end{array}$ & $\begin{array}{c}\text { Fatigue test } \\
\text { No. }\end{array}$ & $\begin{array}{c}\boldsymbol{P}_{\max } / \boldsymbol{P}_{u, \text { exp }} \\
(\%)\end{array}$ & $\begin{array}{c}\text { Fatigue life } \\
\text { (cycles) }\end{array}$ & Failure mode \\
\hline 2 & 1 & 38.7 & $2,000,000$ & $\mathrm{NF}^{1)}$ \\
\hline 3 & 2 & 49.0 & 624,221 & $\mathrm{FS}^{21}$ \\
\hline 4 & 3 & 63.2 & 120,081 & $\mathrm{FS}^{21}$ \\
\hline 2 & 4 & 65.5 & 79,948 & $\mathrm{SC}^{31}$ \\
\hline 5 & 5 & 70.7 & 50,983 & $\mathrm{SC}^{3)}$ \\
\hline 6 & 6 & 82.1 & 11 & $\mathrm{SC}^{3)}$ \\
\hline 7 & 7 & 43.1 & 20 & $\mathrm{DT}^{+1}$ \\
\hline 8 & 8 & 58.5 & 1 & $\mathrm{DT}^{+1)}$ \\
\hline
\end{tabular}

1) NF : no fatigue failure until $2,000,000$ cycles

2) FS: fracture of the lower steel plate at the supporting point (see Fig.1 la)

3) SC: shear compression failure (crushing of concrete between the diagonal cracks)(see Fig. $11 \mathrm{~b}$ )

4) DT : diagonal tension failure (propagation of a main diagonal crack without any crushing of the core concrete)(see Fig.11c)

until about $230 \mathrm{kN}$. At this load, main diagonal cracking occurs in both the experiment and the analysis. This could be illustrated by the crack pattern in Fig.10. Then, the deflection increases further with decreased stiffness until the ultimate failure load. The experimental ultimate failure load $\left(\boldsymbol{P}_{u, \exp }\right)$ was equal to $318 \mathrm{kN}$, while the analytical ultimate failure load $\left(\boldsymbol{P}_{u, F E M}\right)$ was equal to $340 \mathrm{kN}$. In both the experiment and the analysis, the failure mode of the beam was shear compression failure. This failure mode is characterized by diagonal cracking and crushing of concrete as shown in Fig.10.

\section{(2) Fatigue loading}

\section{a) Results of the fatigue tests}

Eight fatigue tests were carried out. The results of the fatigue tests are illustrated in Table 1. The crack patterns of the sandwich beam in fatigue tests no.2, no.5, and no.7 are shown in Fig.11. The numbers written on the crack patterns indicate the number of fatigue loading cycles $(N)$. In fatigue test no.1 $\left(\boldsymbol{P}_{\max }=38.7 \%\right.$ of $\left.\boldsymbol{P}_{\boldsymbol{u}, \exp }\right)$, the fatigue failure did not occur until $2 \times 10^{6}$ cycles. In fatigue tests no. 2 $\left(P_{\max }=49.0 \%\right.$ of $\left.\boldsymbol{P}_{u, \exp }\right)$ and no.3 $\left(\boldsymbol{P}_{\max }=\mathbf{6 3 . 2 \%}\right.$ of $\left.\boldsymbol{P}_{u, \exp }\right)$, fatigue failure occurred due to fracture of the tensile steel plate at the supporting point (see Fig.11a). In fatigue tests no. 2 and no.3, after the formation of the main diagonal cracks, the part of the lower steel plate between the support and the second outer shear connector was subjected to local bending deformations because of the restraint from the support. Also, the largest slip between the concrete and the lower steel plate was observed in this part. Thereafter, the steel plate fractured at the supporting point which was a weak point since the shear connector was welded to the plate and the local bending deformations caused local bending stresses. The cross section of the steel plate at the fractured point is shown at top of Fig.11a, in which the white area indicates the fatigue crack, while the hatched area indicates the part that finally fractured in tension after the growing fatigue crack weakened the plate. In fatigue tests no.4 $\left(\boldsymbol{P}_{\max }=\mathbf{6 5 . 5 \%}\right.$ of 

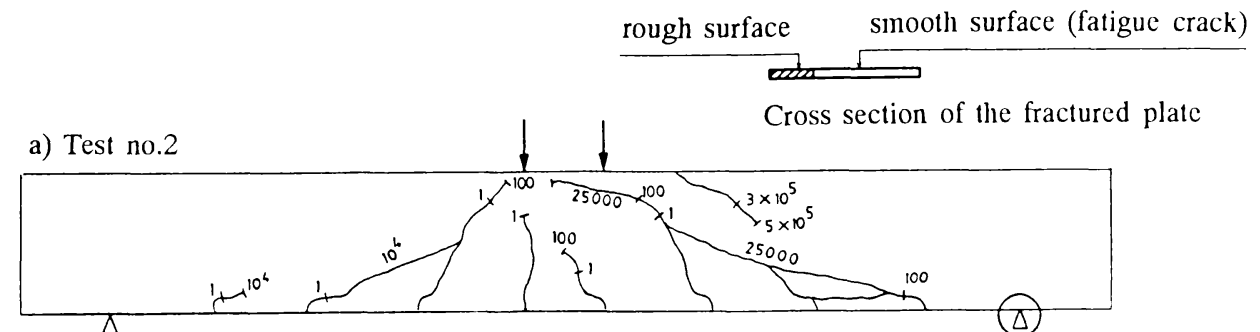

Fracture of plate
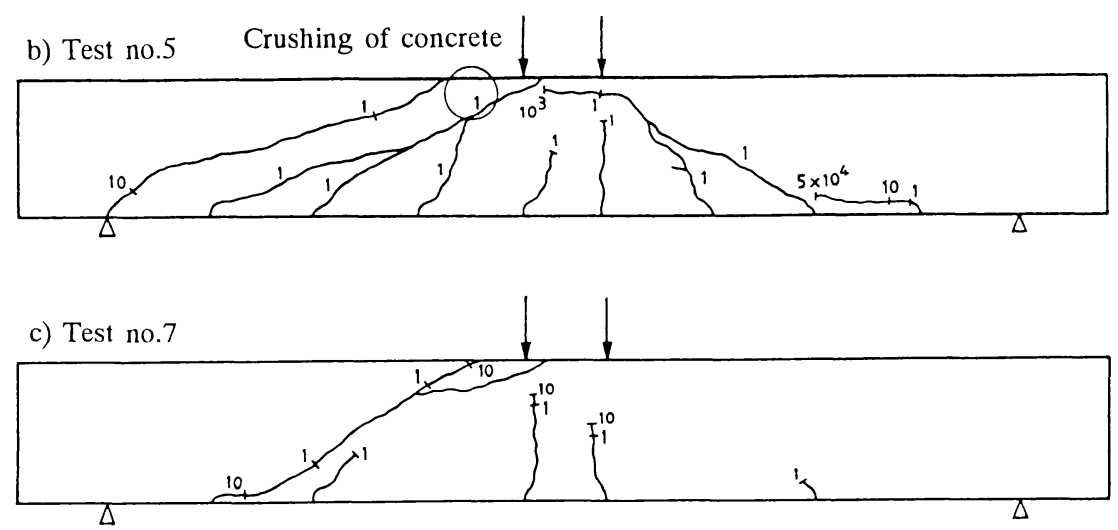

Fig.11 Crack patterns and failure modes under fatigue loading

$\left.\boldsymbol{P}_{u, \exp }\right)$, no.5 $\left(\boldsymbol{P}_{\max }=70.7 \%\right.$ of $\left.\boldsymbol{P}_{u, \exp }\right)$, and no.6 $\left(P_{\max }=82.1 \%\right.$ of $\left.P_{u, \exp }\right)$, fatigue failure occurred due to crushing of concrete between the diagonal cracks (see Fig.11b). In fatigue test no.7 $\left(\boldsymbol{P}_{\max }=\right.$ $43.1 \%$ of $\boldsymbol{P}_{\boldsymbol{u} \text { exp }}$ ), fatigue failure occurred after 20 cycles and the failure mode was a diagonal tension failure (see Fig.11c). In fatigue test no.8 $\left(\boldsymbol{P}_{\max }=\right.$ $58.5 \%$ of $\left.\boldsymbol{P}_{u, \exp }\right)$, the maximum load was designed to be $76 \%$ of $\boldsymbol{P}_{u, \exp }$ but when carrying out the test the sandwich beam failed at $185 \mathrm{kN}$ (i.e.,58.5\% of $\left.\boldsymbol{P}_{u, e x p}\right)$ in the first loading cycle. The failure mode was diagonal tension failure. In fatigue tests no.7 and no.8, the sandwich beam failed due to propagation of a main diagonal crack without any crushing of the core concrete as shown in Fig.11c. This failure mode is different from the one described in section 4(1). The experimental $S$ - $N$ relationship of the sandwich beam is shown in Fig.12. More details about the experimental results can be found in reference 4).

Figure 13 illustrates how the crack pattern affects the failure mode of the sandwich beam. In Fig.13a, diagonal cracks originate from the shear connectors (A) and (B) at the bottom fiber of the sandwich beam. These two diagonal cracks meet each others at point (d) and then propagate with about $30^{\circ}$ angle towards the loading point. Thereafter, another diagonal crack originates from the shear connector $(\mathrm{C})$ at the top fiber of the beam

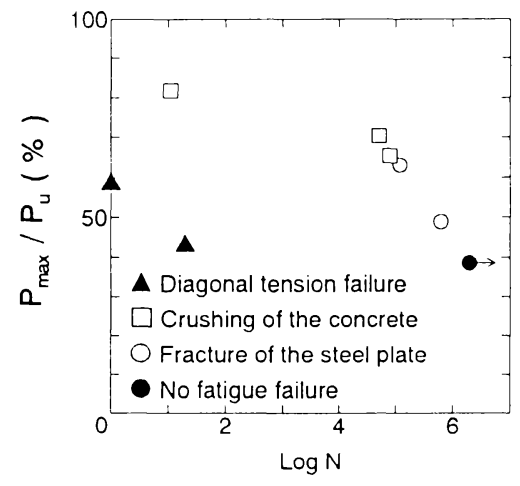

Fig.12 The experimental $S-N$ relationship of the sandwich beam

and then this crack propagates towards the supporting point. Therefore, the tied-arch mechanism appears and finally the sandwich beam fails either by crushing of the concrete compression strut or by fracture of the steel plate at the supporting point. In Fig.13b, the diagonal cracks from points (A) and (B) meet each others at point (d) and then propagate with about $40^{\circ}$ angle towards the loading point. In this case, the crack path becomes close to the shear connector (C). Hence, vertical cracking occurs between the shear connector (C) and the main diagonal crack (see 
Table 2 Results of the fatigue analysis (crushing of concrete failure)

\begin{tabular}{|c|c|c|c|c|c||}
\hline $\begin{array}{c}\text { Beam } \\
\text { No. }\end{array}$ & $\begin{array}{c}\boldsymbol{P}_{\min } \\
(\mathrm{kN})\end{array}$ & $\begin{array}{c}\boldsymbol{P}_{\max } \\
(\mathrm{kN})\end{array}$ & $\begin{array}{c}\boldsymbol{P}_{\max } / \boldsymbol{P}_{\boldsymbol{u}, \text { FEM }} \\
(\%)\end{array}$ & $\begin{array}{c}\text { Fatigue life } \\
(\text { cycles })\end{array}$ & $\begin{array}{c}\text { Failure } \\
\text { mode }\end{array}$ \\
\hline 1 & 20 & 240 & 70.6 & 20,000 & $\mathrm{SC}^{1)}$ \\
\hline 2 & 20 & 270 & 79.4 & 1,000 & $\mathrm{SC}^{1)}$ \\
\hline 3 & 20 & 300 & 88.2 & 50 & $\mathrm{SC}^{1)}$ \\
\hline
\end{tabular}

1) SC: shear compression failure (crushing of the core concrete)

Fig.13b). Therefore, the tied-arch mechanism cannot appear and diagonal tension failure occurs for the sandwich beam. It is noted that the diagonal cracks originate at the locations of the shear connectors and then these cracks propagate with increasing the number of loading cycles $(\boldsymbol{N})$. Therefore, it could be said that the arrangement of the shear connectors affects the failure mode of the sandwich beam.

\section{b) Results of the fatigue analysis}

The fatigue strength of the sandwich beam with the crushing of concrete failure was predicted by using the finite element method. The sandwich beam was analyzed for different external load ranges. The minimum fatigue load $\left(\boldsymbol{P}_{\min }\right)$ was kept constant at $20 \mathrm{kN}$. The maximum fatigue load $\left(\boldsymbol{P}_{\max }\right)$ was chosen to be $240 \mathrm{kN}, 270 \mathrm{kN}$, and 300 $\mathrm{kN}$ which is $70.6 \%, 79.4 \%$, and $88.2 \%$, respectively of the analytical static strength of the beam $\left(\boldsymbol{P}_{u, F E M}=340 \mathrm{kN}\right)$. The analytical results are summarized in Table 2. The output load-deflection curves for beams no. 2 and no. 3 are shown in Fig.14. Note that the overall stiffness of the beam decreases in the second and third loading cycles because of increasing the crack propagation and finally the beam fails due to crushing of concrete at the maximum fatigue load. The analytical $S-N$ relationship of the sandwich beam is shown in Fig.15a, and also compared with the experimental one for the same failure mode (i.e., the crushing of concrete failure mode). Good agreement is observed between the experimental and the analytical $S-N$ relationships.

Then, a sensitivity analysis was carried out to clarify the effect of each reduction in four factors, i.e., the compressive strength $\left(f_{c}{ }^{\prime}\right)$, the tensile strength $\left(f_{t}\right)$, the stiffness of concrete $\left(\boldsymbol{E}_{c}\right)$, and the shear modulus $\left(\boldsymbol{G}_{c}\right)$ on the fatigue strength of the sandwich beam. The analysis was carried out for the beam no. 2 in Table 2 . The analysis indicated that none of the reduction of the sole factor could explain fully the strength reduction due to fatigue. Some factors affected the fatigue strength more a)

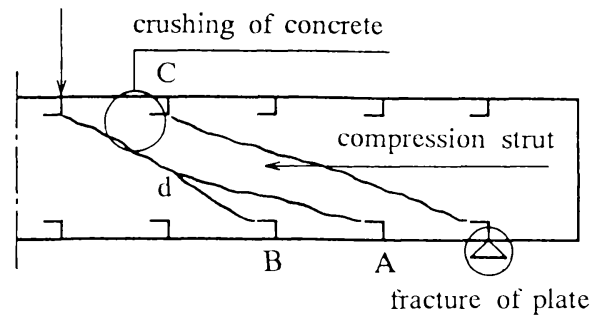

b)

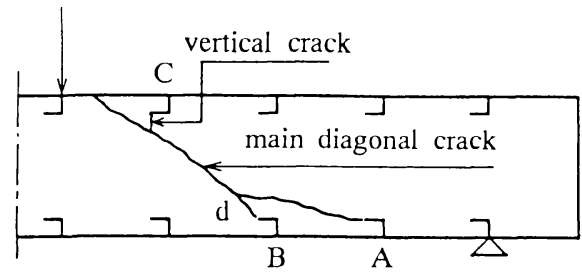

Fig.13 Effect of the crack pattern on the failure mode of the sandwich beam

significantly than others. A comparison of the predicted fatigue lives with the reduction of different combinations of factors is shown in Table 3. If the reduction is made for all the factors $\left(f_{c}{ }^{\prime}\right.$, $\boldsymbol{f}_{\boldsymbol{c}}, \boldsymbol{E}_{\boldsymbol{c}}, \boldsymbol{G}_{\boldsymbol{c}}$ ), the fatigue life of the beam is 1000 cycles. It is observed that the most influential factor on the fatigue life of the beam is the tensile strength of concrete $\left(f_{t}\right)$ because if $\left(f_{t}\right)$ is kept constant and the reduction is made for all the other factors $\left(f_{c}{ }^{\prime}\right.$, $\left.\boldsymbol{E}_{c}, \boldsymbol{G}_{\boldsymbol{c}}\right)$, the fatigue life of the beam will increase to 1200 cycles. The shear modulus $\left(\boldsymbol{G}_{\boldsymbol{c}}\right)$ has also some effect on the fatigue life of the beam because when $\left(\boldsymbol{G}_{\boldsymbol{c}}\right)$ is kept constant and the reduction is made for $\left(f_{c}{ }^{\prime}, f_{t}, E_{c}\right)$, the fatigue life of the beam increased to 1100 cycles. However, when the concrete compressive strength $\left(f_{c}{ }^{\prime}\right)$ is kept constant and when the stiffness of concrete $\left(\boldsymbol{E}_{c}\right)$ is kept constant, the fatigue lives of the beam remain the same as shown in Table 3. It was found by the analysis that the most influential factor was the concrete tensile strength $\left(f_{t}\right)$, the second was the shear modulus at crack $\left(\boldsymbol{G}_{\boldsymbol{c}}\right)$, the third was the stiffness of concrete $\left(\boldsymbol{E}_{c}\right)$, and the least was the compressive strength $\left(f_{c}{ }^{\prime}\right)$. It could be said from the analysis that the 

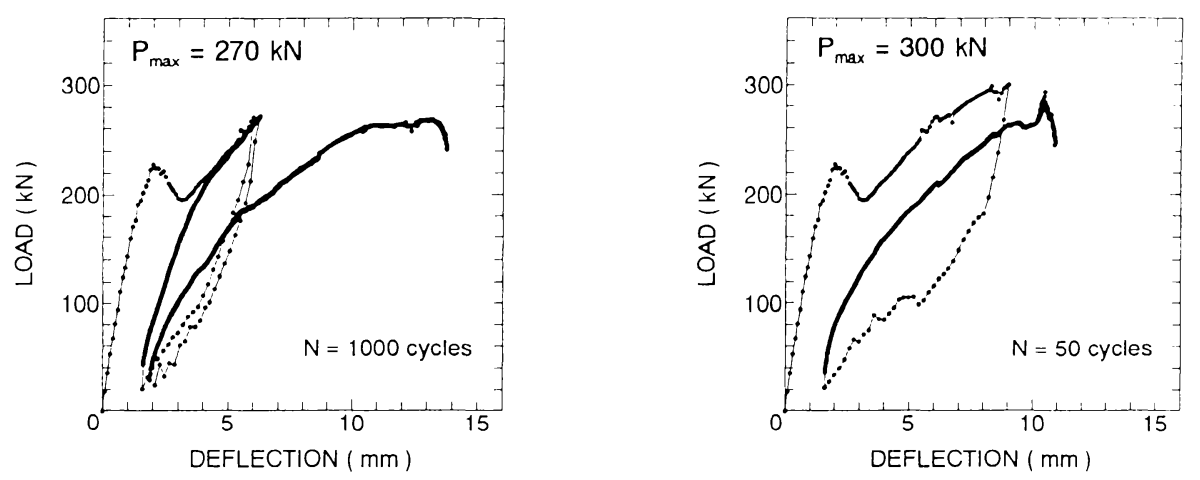

Fig.14 The analytical load-deflection curves

a)

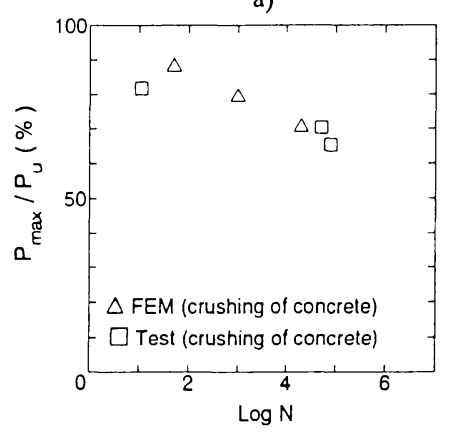

b)

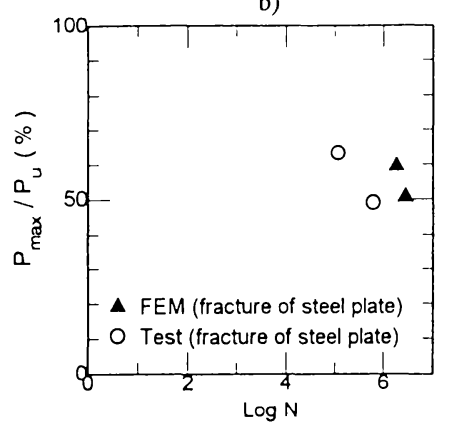

Fig.15 Comparison between the experimental and the analytical $S$ - $N$ relationships

Table 3 Results of the sensitivity fatigue analysis

\begin{tabular}{|c|c|c|c|c|c|}
\hline & $\begin{array}{c}\text { Reduction for } \\
\left(f_{c}^{\prime}, f_{t}, E_{c}, G_{c}\right)\end{array}$ & $\begin{array}{c}\text { Reduction for } \\
\left(f_{t}, E_{c}, G_{c}\right) \text { only }\end{array}$ & $\begin{array}{c}\text { Reduction for } \\
\left(f_{c}^{\prime}, E_{c}, G_{c}\right) \text { only }\end{array}$ & $\begin{array}{c}\text { Reduction for } \\
\left(f_{c}^{\prime}, f_{t}, G_{c}\right) \text { only }\end{array}$ & $\begin{array}{c}\text { Reduction for } \\
\left(f_{c}^{\prime}, f_{t}, E_{c}\right) \text { only }\end{array}$ \\
\hline $\begin{array}{c}\text { Fatigue life } \\
\text { (cycles) }\end{array}$ & 1000 & 1000 & 1200 & 1000 & 1100 \\
\hline
\end{tabular}

crack propagation and the increase in the shear deformation due to the reduction of these factors cause earlier shear compression failure under fatigue loading.

The fatigue strength of the sandwich beam with the fracture of steel plate failure was also predicted by using the finite element method. The sandwich beam was analyzed for two different external load ranges. The minimum fatigue load $\left(\boldsymbol{P}_{\min }\right)$ was kept constant at $20 \mathrm{kN}$. The maximum fatigue load $\left(\boldsymbol{P}_{\max }\right)$ was chosen to be $50.7 \%$ and $59.6 \%$ of the analytical static strength of the beam $\left(\boldsymbol{P}_{\boldsymbol{u}, \text { FEM }}=340\right.$ $\mathrm{kN})$. The fatigue analysis was carried out by the following procedure:

- At first, a static loading cycle (OAB) is applied as shown in Fig.4.

- The maximum tensile stress in the lower steel plate at the location of the second outer shear connector is stored at point (A). Similarly, the minimum tensile stress in the lower steel plate at the location of the second outer shear connector is stored at point (B). Hence, the stress range in the lower steel plate at the location of the second outer shear connector is calculated. This location was selected because the strains in the lower steel plate at this point were recorded in fatigue test no.2 (see Table 1). Therefore, it is possible to estimate the additional stresses induced in the steel plate due to the local bending deformations as well as the additional stresses due to the shear transfer 
Table 4 Results of the fatigue analysis (fracture of steel plate failure)

\begin{tabular}{|c|c|c|c|c|c|}
\hline $\begin{array}{c}\text { Beam } \\
\text { No. }\end{array}$ & $\begin{array}{c}\boldsymbol{P}_{\min } \\
(\mathrm{kN})\end{array}$ & $\begin{array}{c}\boldsymbol{P}_{\max } \\
(\mathrm{kN})\end{array}$ & $\begin{array}{c}\boldsymbol{P}_{\max } / \boldsymbol{P}_{u, F E M} \\
(\%)\end{array}$ & $\begin{array}{c}\text { Fatigue life } \\
(\text { cycles })\end{array}$ & $\begin{array}{c}\text { Failure } \\
\text { mode }\end{array}$ \\
\hline 1 & 20 & 172 & 50.7 & $2,735,000$ & $\mathrm{FS}^{1)}$ \\
\hline 2 & 20 & 203 & 59.6 & $1,820,000$ & $\mathrm{FS}^{1)}$ \\
\hline
\end{tabular}

1) FS : fracture of the lower steel plate

between the concrete and the lower steel plate. Unfortunately, the strain measurements at the actual fractured point (i.e., the supporting point) were not available and therefore, the location of the second outer shear connector was selected.

- Then, the calculated stress range is multiplied by an amplification factor to account for the effect of the local bending deformations of the steel plate as well as the effect of the shear transfer between the concrete and the lower steel plate. In this study, the amplification factor was approximately equal to 5.0. This amplification factor was obtained by comparing the stress range of the steel plate measured in fatigue test no.2 (see Table 1) with the stress range measured in the fatigue test in air ${ }^{12}$.

- Then, using the $S_{r}-N$ relationship of the steel plate in air $^{12}$ and knowing the value of the amplified stress range, the number of loading cycles $\left(N_{F}\right)$ can be calculated as shown in Fig.16.

- If the input number of cycles $\left(N_{I}\right)$ is equal to the calculated one $\left(N_{F}\right)$, the sandwich beam is considered to fail due to fracture of the lower steel plate after the loading cycles $\left(\boldsymbol{N}_{I}\right)$.

The analytical results are summarized in Table 4. The analytical $S-\boldsymbol{N}$ relationship of the sandwich beam is shown in Fig.15b, and also compared with the experimental one for the same failure mode (i.e., the fracture of steel plate failure mode).

\section{DESIGN PROPOSAL FOR SANDWICH BEAMS}

This chapter presents a procedure which can be used to design steel-concrete sandwich beams under fatigue loading. The design procedure is explained by the chart in Fig.17. The design procedure can be summarized as follows,

1- Choose the values of the maximum and minimum fatigue loads $\left(\boldsymbol{P}_{\max }\right.$ and $\left.\boldsymbol{P}_{\text {min }}\right)$ considering actual loading conditions and decide the required fatigue life of the sandwich beam $\left(N_{\text {req }}\right)$.

2- Select the geometry of the sandwich beam and the material properties (i.e., the concrete

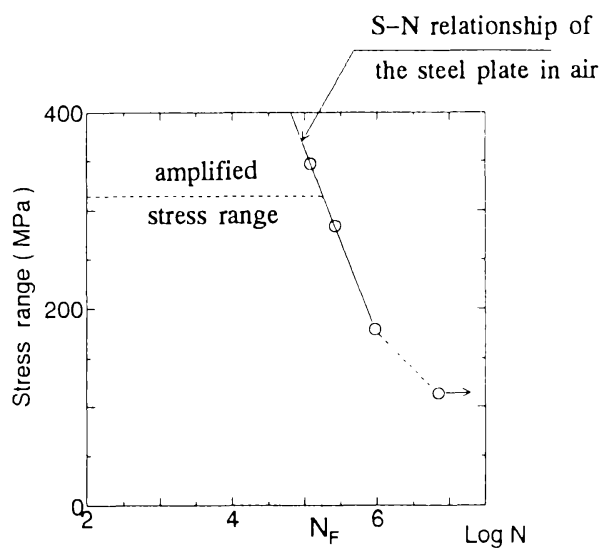

Fig.16 Prediction for the fatigue life of the beam failing due to fracture of the steel plate

compressive strength, the yielding point, and the tensile strength of the steel plates).

3- Evaluate the static load carrying capacity of the beam $\left(\boldsymbol{P}_{u}\right)$ by the finite element method, by using a design code equation ${ }^{1)}$, or by carrying out a static loading test.

4- Knowing the percentage of $\left(\boldsymbol{P}_{\max } / \boldsymbol{P}_{u}\right)$, the $\boldsymbol{S}$ - $\boldsymbol{N}$ relationship in Fig.15a can be used to predict the fatigue life of the sandwich beam failing due to crushing of concrete.

5- Using the bending theory, calculate the stress range in the tension steel plate at the maximum bending moment section, which can conservatively approximate the average stress range at a potential section of fracture of the tension steel plate.

6- This calculated stress range should be multiplied by an amplification factor $(\alpha)$ to account for the effect of the local bending deformations of the tension steel plate as well as the effect of the shear transfer between the concrete and the tension steel plate. In the present study, this amplification factor $(\alpha)$ was approximately equal to 5.0.

7- Then, using the $S_{r}-N$ relationship of the steel plate in air ${ }^{12}$ (see Fig.16) and the stress range 


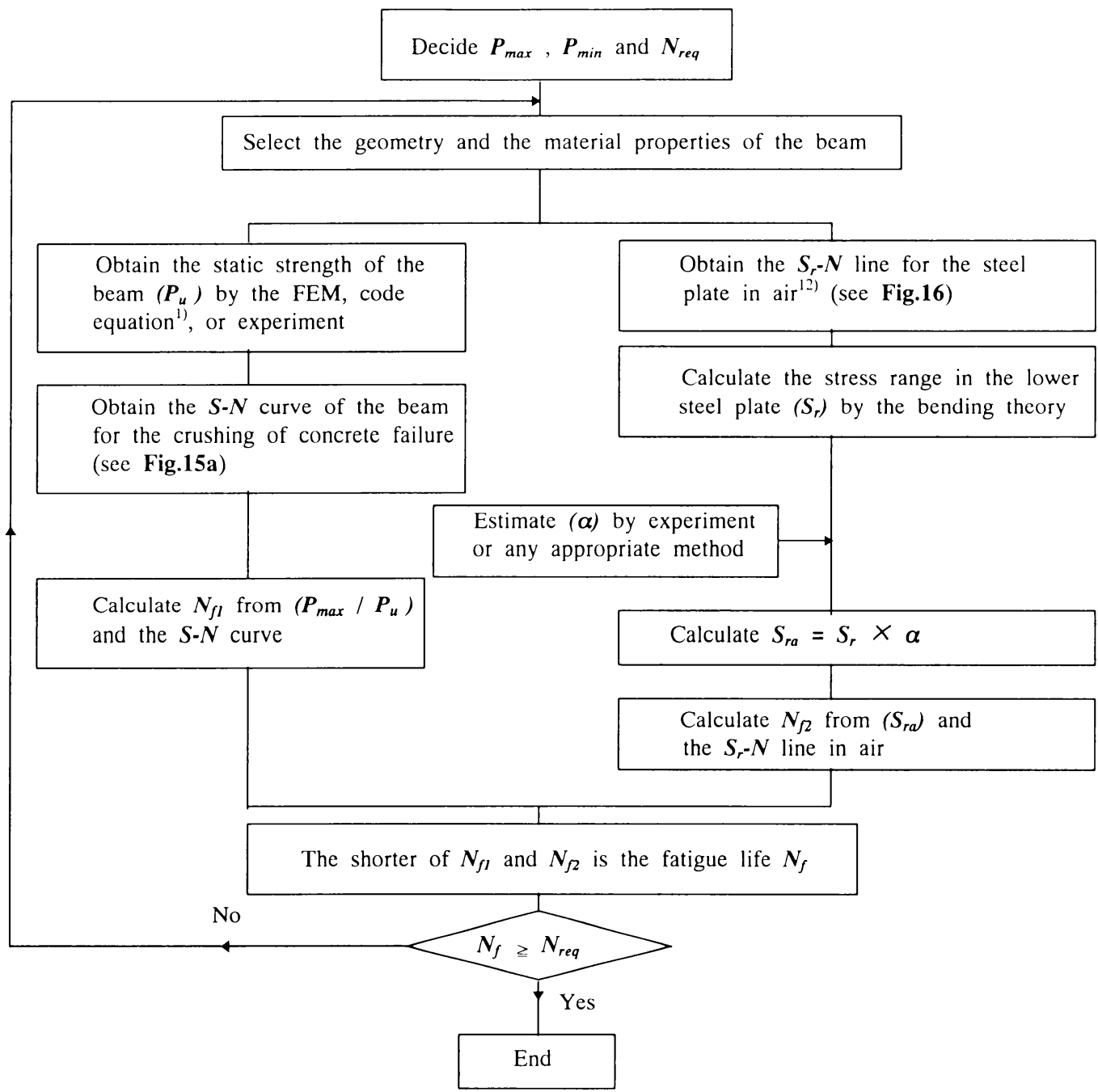

Fig.17 Design procedure for sandwich beams

calculated in step 6 , the fatigue life of the sandwich beam failing due to fracture of the tension steel plate can be calculated as shown in Fig.16.

8- The shorter of the fatigue lives calculated in steps 4 and 7 should be selected as the fatigue life of the sandwich beam $\left(N_{f}\right)$.

9- If $\boldsymbol{N}_{f}$ is less than the required fatigue life $\left(\boldsymbol{N}_{\text {req }}\right)$, the dimensions and the material properties of the beam should be changed until $N_{f}$ becomes equal to or longer than $N_{\text {req. }}$.

\section{CONCLUSIONS}

(1) For large maximum fatigue loads $\left(\boldsymbol{P}_{\max }=65.5 \%\right.$, $70.7 \%$, and $82.1 \%$ of the static strength), the failure mode of the beam is crushing of concrete between diagonal cracks, but for smaller loads $\left(\boldsymbol{P}_{\max }=\right.$ $49.0 \%$ and $63.2 \%$ of the static strength), the failure mode is fracture of the tension steel plate at the supporting point.

(2) The sandwich beam investigated in this study indicates also diagonal tension failure mode. In this case, the beam fails due to propagation of a main diagonal crack without any crushing of the core concrete. It was observed that the crack pattern affects the failure mode of the beam. The diagonal cracks always originate at the locations of the shear connectors and then these cracks propagate with increasing the number of loading cycles. Therefore, it could be said that the arrangement of the shear connectors affects the failure mode of the beam. 
However, further study is needed to clarify the shear fatigue behavior of sandwich beams with tension shear failure mode.

(3) The fatigue strength of the beam with the crushing of concrete failure could be predicted by using the finite element method in which the compressive strength, the tensile strength, and the stiffness of the concrete are reduced with increasing the number of cycles $(N)$ or increasing the stress range $\left(S_{r}\right)$. However, it is simply assumed that Eq.(1) is applicable to the biaxial state of stresses. Further study is necessary to prove this assumption by fatigue tests of concrete elements under biaxial stress conditions.

(4) The fatigue strength of the beam with the fracture of steel plate failure could be predicted by using the finite element method. The stress range in the tension steel plate is multiplied by an amplification factor to account for the effect of the local bending deformations of the steel plate as well as the effect of the shear transfer between the concrete and the tension steel plate. Then, for an input number of cyctes, the $S_{r}-N$ relationship of the steel plate in air $^{12)}$ is used to check whether the steel plate fractured or not.

(5) Based on the results of this study, a design proposal for the sandwich beams under fatigue loading is presented.

ACKNOWLEDGMENTS: This study was conducted as a part of the doctoral dissertation of the first author submitted to Hokkaido University. The first author is indebted to the Ministry of Education, Science and Culture, Japan for the Monbusho Scholarship. The authors are also grateful to the Grant-in-Aid for Scientific Research(B) (No.06555123) which supported this study partially. The authors would like to express their gratitude to the members of the Department of Civil Engineering in Sumitomo Construction Co., Ltd., for providing the facility to continue the analytical study of this research work.

\section{REFERENCES}

1) JSCE Research Subcommittee on Steel-Concrete Sandwich Structures: Design Code for Steel-Concrete Sandwich Structures - Draft, Concrete Library of JSCE, No.20, pp.1-21, December 1992.

2) Yokota, H. and Kiyomiya, O.: Fatigue Behaviours of Steel-Concrete Hybrid Beams, Transactions of the JCI, Vol.11, pp.455-462, 1989.

3) Kiyomiya, O. and Yokota, H.: Fundamental Mechanical Properties of Steel - Concrete Hybrid Beams for Marine Environment, Proceedings of the Third International Conference on Steel-Concrete Composite Structures, Fukuoka, Japan, pp.527-532, September 1991.

4) Zahran, M., Kanaya, K., Ueda, T. and Kakuta, Y.: ShearFatigue Behavior of Steel-Concrete Sandwich Beams Without Web Reinforcement, Transactions of the JCI,Vol.16, pp.431-438, 1994.

5) Zahran, M., Ueda, T. and Kakuta, Y.: Analytical Evaluation for the Fatigue Strength of Steel-Concrete Sandwich Beams Without Shear Reinforcement, Proceedings of the International Conference on Concrete Under Severe Conditions, Sapporo, Japan, pp.1684-1693, August 1995.

6) Okamura, H. and Maekawa, k.: Nonlinear Analysis and Constitutive Models of Reinforced Concrete, Gihodo Shuppan, Tokyo, pp.1-25, 1991.

7) Pantaratorn, N.: Finite Element Analysis on Shear Resisting Mechanism of RC Beams, Dissertation Submitted to the University of Tokyo, pp.74-102, March 1991.

8) Tepfers, R. and Kutti, T.: Fatigue Strength of Plain, Ordinary, and Lightweight Concrete, ACIJournal, Vol.76, No.5, pp.635-652, 1979.

9) Tepfers, R. : Tensile Fatigue Strength of Plain Concrete, ACI Journal, Vol.76, No.8, pp.919-933, 1979.

10) Holmen, J.O.: Fatigue of Concrete Structures, $A C I$, SP-75, Detroit, pp.71-110, 1982.

11) Bennett, E.W. and Raju, N.K.: Cumulative Fatigue Damage of Plain Concrete in Compression, The Proceedings of the Southampton 1969 Civil Engineering Materials Conference, 1089-1102, 1969.

12) Zahran, M., Ueda, T. and Kakuta, Y.: A Study on the Fatigue Fracture of Steel Plates in Steel-Concrete Sandwich Beams, Proceedings of the JSCE Conference, Vol.50, pp.232-233, 1995.

(Received November 6, 1996)

\title{
せん断補強のない鋼コンクリートサンドイッチ梁のせん断疲労
}

\author{
Mohab ZAHRAN ·上田 多門 ·角田 與史雄
}

\begin{abstract}
せん断補強のない鋼コンクリートサンドイッチ梁の疲労試験を行い，観察されたせん断疲労破壊モ一 ドおよびそのS-N曲線を示した. 次に, 繰り返し回数および応力振幅に伴うコンクリートの圧縮強度, 引 張強度, 剛性の低下を構成則に取り入れた有限要素解析により, 各せん断疲労破壊モードのS-N曲線を推 定できることを示した，最後に，せん断補強のない鋼コンクリートサンドイッチ梁のせん断疲労に対する 設計法を提示した.
\end{abstract}

